\title{
Review \\ Does diet affect breast cancer risk?
}

\author{
Michelle D Holmes ${ }^{1}$ and Walter C Willett ${ }^{1-3}$
}

\author{
${ }^{1}$ Channing Laboratory, Department of Medicine, Harvard Medical School and Brigham and Women's Hospital, Boston, Massachusetts, USA \\ ${ }^{2}$ Department of Nutrition, Harvard School of Public Health, Boston, Massachusetts, USA \\ ${ }^{3}$ Department of Epidemiology, Harvard School of Public Health, Boston, Massachusetts, USA \\ Corresponding author: Michelle D Holmes, michelle.holmes@channing.harvard.edu \\ Published: 17 June 2004
}

Breast Cancer Res 2004, 6:170-178 (DOI 10.1186/bcr909)

(c) 2004 BioMed Central Ltd (Print ISSN 1465-5411; Online ISSN 1465-542X)

\begin{abstract}
The role of specific dietary factors in breast cancer causation is not completely resolved. Results from prospective studies do not support the concept that fat intake in middle life has a major relation to breast cancer risk. However, weight gain in middle life contributes substantially to breast cancer risk. Alcohol is the best established dietary risk factor, probably by increasing endogenous estrogen levels. Hypotheses relating diet during youth to risk decades later will be difficult to test. Nevertheless, available evidence is strong that breast cancer risk can be reduced by avoiding weight gain during adult years, and by limiting alcohol consumption.
\end{abstract}

Keywords: breast neoplasms, diet, ethanol, obesity, women

\section{Introduction}

Breast cancer incidence rates vary widely around the world. Also, the offspring of those who migrate from countries with low incidence to countries with high incidence take on the higher rates of the new host country [1]. These observations have promoted the hypothesis that nutrition is an environmental determinant of breast cancer. The dominant hypothesis has been that high fat intake increases risk. We review evidence for this relationship and other potential dietary risk factors for breast cancer.

\section{Dietary fat and breast cancer Animal studies}

High-fat diets have long been known to increase the occurrence of mammary tumors in rodents. However, the interpretation of animal data is controversial. Fat is the most energy-dense macronutrient; therefore, it is sometimes difficult to disentangle the effects of fat intake from those of energy intake in studies of cancer. In studies specifically designed to determine the independent effects of fat and energy intake, the effect of fat was either weak in relation to that of energy intake [2] or it was nonexistent [3]. Furthermore, in these experiments rodents are given high doses of carcinogens, and the relevance to human cancer is questionable. The clearest message from the animal data is the importance of total energy intake.

\section{International correlation (ecologic) studies}

The dietary fat hypothesis is largely based on the observation that national per capita fat consumption is highly correlated with breast cancer mortality rates [4]. However, per capita fat consumption is highly correlated with economic development. Also, low parity and late age at first birth, greater body fat, and lower levels of physical activity are more prevalent in Western countries, and would be expected to confound the association with dietary fat.

\section{Secular trends}

Both per capita fat consumption and breast cancer incidence rates increased substantially in the USA during the 20th century. However, estimates of per capita fat consumption are based on 'food disappearance' (the food available rather than the amount actually eaten). Surveys based on measures of actual individual intake indicate that consumption of fat as a percentage of energy has actually declined during the past several decades. 
Table 1

\begin{tabular}{|c|c|c|c|c|c|}
\hline \multirow[b]{2}{*}{ Study [ref.] } & \multirow{2}{*}{$\begin{array}{l}\text { Total number } \\
\text { in cohort }\end{array}$} & \multirow{2}{*}{$\begin{array}{l}\text { Years of } \\
\text { follow-up }\end{array}$} & \multirow{2}{*}{$\begin{array}{l}\text { Number } \\
\text { of cases }\end{array}$} & \multicolumn{2}{|c|}{$\mathrm{RR}(95 \% \mathrm{Cl}$; high versus low category) } \\
\hline & & & & Total fat & Saturated fat \\
\hline Nurses' Health Study [96] & 89,494 & 8 & 1439 & $0.86(0.67-1.08)$ & $0.86(0.73-1.02)$ \\
\hline Nurses' Health Study [12] & 88,795 & 14 & 2956 & $0.97(0.94-1.00)^{\mathrm{a}}$ & $0.94(0.88-1.01)^{a}$ \\
\hline Canadian study [97] & 56,837 & 5 & 519 & $1.30(0.90-1.88)$ & $1.08(0.73-1.59)$ \\
\hline New York State cohort [98] & 17,401 & 7 & 344 & $1.00(0.59-1.70)$ & $1.12(0.78-1.61)^{\mathrm{b}}$ \\
\hline lowa women's study [99] & 32,080 & 4 & 408 & $1.13(0.84-1.51)$ & $1.10(0.83-1.46)$ \\
\hline Dutch health study [100] & 62,573 & 3 & 471 & $1.08(0.73-1.59)$ & $1.39(0.94-2.06)$ \\
\hline Adventists health study [104] & 20,341 & 6 & 193 & - & $1.21(0.81-1.81)$ \\
\hline Swedish mammography screening cohort [101] & 61,471 & 6 & 674 & $1.00(0.76-1.32)$ & $1.09(0.83-1.42)$ \\
\hline Breast Cancer Detection Demo Project [102] & 40,022 & 5 & 996 & $1.07(0.86-1.32)$ & $1.12(0.87-1.45)$ \\
\hline California teachers study [103] & 115,526 & 2 & 711 & $0.8(0.6-1.2)$ & $0.8(0.6-1.2)$ \\
\hline
\end{tabular}

${ }^{a}$ Animal fat. ${ }^{b}$ Continuous. $\mathrm{Cl}$, confidence interval; RR, relative risk. From Willett and coworkers [95].

Data from populations with distinct dietary patterns are potentially valuable. These groups often follow diets prescribed by religious rules, and may represent a more stable long-term exposure than is found in most adults. However, these populations often have unusual distributions of other risk factors such as alcohol consumption, smoking, and reproductive behavior. Therefore, care must be taken in attributing differences in cancer rates to diet alone.

Seventh-Day Adventists, who consume relatively small amounts of meat and other animal products, have substantially lower rates of colon cancer but only slightly lower breast cancer rates than do other US women [5]. Breast cancer rates among UK nuns who ate little to no meat were similar to rates among single women from the general population [6], also suggesting that there is no substantial association between animal fat intake and risk for breast cancer.

\section{Case-control studies}

Howe and coworkers [7] performed a meta-analysis of 12 case-control studies including a total of 4312 cases. The overall pooled relative risk (RR) for a $100 \mathrm{~g}$ increase in daily total fat intake was 1.35 , with greater risk among postmenopausal women $(R R=1.48)$ and no association in premenopausal women $(R R=1.13)$. However, the average total fat consumption is about $70 \mathrm{~g} /$ day in US women. A reduction in fat intake as large as $100 \mathrm{~g}$ would not be feasible, but the RR for readily achievable changes in total fat intake would be relatively small. For example, there would be only a 10\% decrease in risk among postmenopausal women corresponding to a decrease from $40 \%$ to $29 \%$ of calories of fat intake. RRs of this magnitude in case-control studies may easily be due to selection or recall bias [8].

The association of childhood dietary fat intake with breast cancer risk has been assessed retrospectively because of the difficulty in performing prospective studies. One study including 1647 cases of breast cancer in young women [9] reported a slightly increased risk for breast cancer with adolescent intake of high-fat meat. In a retrospective cohort study of 47,355 women based on the Nurses' Health Study II, intake of total fat during high school was not associated with breast cancer risk, but intake of vegetable fat was associated with decreased risk [10].

\section{Cohort studies}

In a cohort (prospective) study selection bias and recall bias should not occur. The results for postmenopausal breast cancer from prospective studies with at least 200 incident cases of breast cancer are shown in Table 1. Not one study reported a significant positive association with total fat intake. A collaborative pooled analysis that included most of the studies shown in Table 1 comprised a total of 4980 breast cancer cases among 337,819 women [11]. Overall, no association was observed between intake of total, saturated, monounsaturated, or polyunsaturated fat and risk for breast cancer. No reduction in risk was seen even for fat intakes as low as $20 \%$ of energy.

In the Nurses' Health Study, additional analyses were conducted with 14 years of follow-up (2956 cases) [12]; up to four assessments of fat intake were available, which substantially improves the measurement of long-term dietary intake. The RR for a $5 \%$ increase in percentage of 
energy from total fat was 0.97 (95\% confidence interval [Cl] = 0.94-1.00); the overall weak trend was actually statistically significant (inverse), and no suggestion of any reduction in risk was seen for fat intakes even lower than $20 \%$ of energy. In addition, results were no different when using only the baseline diet assessment: RR $(95 \% \mathrm{Cl})=$ 0.99 (0.87-1.01). Thus, the prospective studies provide strong evidence that no major relation exists between total dietary fat intake over a wide range during midlife and breast cancer incidence. Some researchers hypothesize that systematic and random measurement error occurs when using food frequency questionnaires in cohort studies, which has obscured an association between fat intake and breast cancer [13]. However, the theoretical biases needed to account for a lack of association are extreme, and were not supported by empirical evidence [14].

\section{Intervention studies}

Some have suggested that the relation between dietary fat and breast cancer can only be established by randomized trials of fat reduction. The Women's Health Initiative sponsored by the US National Institutes of Health randomly assigned women to one of two groups [15]: in one group $(n=19,541)$ the women reduced their total fat intake to $20 \%$ of calories and in the other group ( $n=29,294$; control group) the women consumed their usual diet. In addition, two ongoing trials (Women's Intervention Nutrition Study and the Women's Healthy Eating and Living Study) are being conducted in women with breast cancer to determine whether a low-fat dietary intervention will prevent recurrence and improve survival $[16,17]$.

However, it is difficult to maintain compliance with a diet that is very different from prevailing food consumption habits. Also, a secular decline in fat consumption is already underway. These two facts may reduce the difference in fat intake between the intervention group and controls, and may compromise the ability to detect a difference in cancer rates. Furthermore, women in the dietary intervention group of the Women's Health Initiative will be counseled to adopt a dietary pattern high in fruits, vegetables, and grains, as well as low in fat [18]. Thus, the trial would be unable to distinguish between a decrease in risk due to increased intake of fruits, vegetables and grains, and a decrease due to lower fat intake. Also, that trial will not determine whether dietary fat reduction at an earlier age may reduce breast cancer risk.

\section{Type of fat}

Specific types of fat could differentially affect risk for breast cancer. In most animal studies diets high in polyunsaturated fat, but typically at levels beyond human exposure, have clearly increased the occurrence of mammary tumors. A positive association has not been
In a pooled analysis of cohort studies [19], saturated fat (compared with carbohydrate) was weakly associated with higher risk for breast cancer (RR for $5 \%$ of energy $=1.09$; 95\% Cl $=1.00-1.19)$. In a recent prospective study conducted in premenopausal women in the Nurses' Health Study II [20], intake of animal fat and high-fat dairy foods was associated with a 33-36\% increase in risk for breast cancer for the highest compared with the lowest quintile of intake. Total fat per se was not associated with breast cancer risk, suggesting that other constituents of dairy foods consumed early in adult life may increase breast cancer risk.

\section{Childhood energy balance}

As noted earlier, energy restriction powerfully reduces mammary tumors in rodents. The World War II Norwegian famine provided a natural human experiment [21]. Female adolescents who lived through the famine have had a slightly lower breast cancer risk at all later ages - 13\% reduction in breast cancer risk. However, the timing and duration of energy deprivation may be important. The risk of breast cancer was increased among women exposed to the short but severe 1944-45 Dutch famine, and the elevation in risk was strongest (double compared with unexposed) for those exposed between the ages of 2 and 9 years [22].

Energy-deprived children do not attain full height, which may be used as a proxy for childhood energy intake. Most observational studies of height and breast cancer risk suggest a modest positive association [23-26]. In a pooled analysis of large cohorts (4385 cases), the RRs for an increment of $5 \mathrm{~cm}$ in height were $1.02(95 \% \mathrm{Cl}=0.96-$ 1.10) for premenopausal and $1.07(95 \% \mathrm{Cl}=1.03-1.12)$ for postmenopausal women (Fig. 1) [27].

Age at menarche - an established breast cancer risk factor - also indicates childhood energy balance. In prospective studies, weight, height, and body fat predict age at menarche $[28,29]$. The potential for energy balance to influence breast cancer risk through age at menarche is great. Although the average age at menarche in Western countries is $12-13$ years, in rural China the typical age has been 17-18 years [30], which is similar to that in Western countries 200 years ago.

\section{Adulthood energy balance}

Attained weight and weight change in adults provide sensitive measures of energy balance. Two findings have been particularly enigmatic. First, in affluent Westerners, body fat has been inversely related to premenopausal breast cancer risk. Second, body fat has been only weakly related to increased postmenopausal risk, despite strong links with endogenous estrogen levels.

The inverse relation between body weight (typically body mass index [BMI] calculated as $\mathrm{kg} / \mathrm{m}^{2}$ ) and premeno- 


\section{Figure 1}

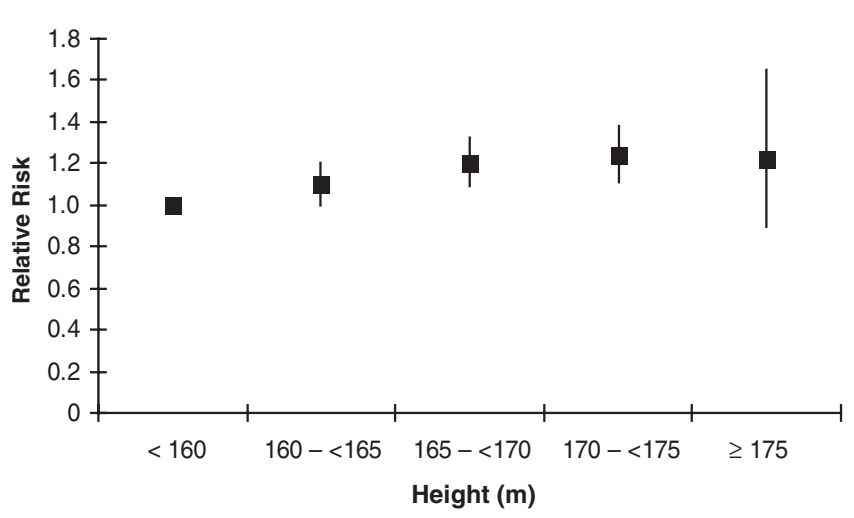

Height and breast cancer. Results of prospective studies of the association between height and breast cancer. Reproduced from van der Brandt PA and coworkers [27], with permission.

pausal breast cancer has consistently been seen in observational studies [27,31]. Heavier premenopausal women have more irregular menstrual cycles and anovulatory infertility [32], suggesting their lower risk may be due to lower ovarian hormones [33].

In observational studies, the association between BMI and postmenopausal breast cancer risk has been only weakly positive or nonexistent $[7,23,27]$. This is surprising because obese postmenopausal women have endogenous estrogen levels nearly double those of lean women [34]. This lack of association appears due to two factors. First, the early adult reduction in breast cancer risk due to being overweight appears to persist [31,35], opposing the adverse effect of elevated estrogens after menopause. Thus, weight gain should be more strongly related to postmenopausal breast cancer risk than attained weight. Indeed, this was true in both case-control [36,37] and prospective studies [31,35,38,39]. Second, use of postmenopausal hormones obscures the variation in endogenous estrogens due to adiposity and elevates breast cancer risk regardless of body weight [31,39]. Among never-users of postmenopausal hormones, those gaining at least $25 \mathrm{~kg}$ after age 18 years had double the breast cancer risk of women who maintained their weight (Fig. 2) [31].

In a recent pooled analysis of eight prospective studies of postmenopausal women including 624 cases [40], the authors reported that breast cancer risk increased with increasing BMI, and that this elevated risk was substantially attenuated by adjustment for serum estrogen concentrations.

An expert panel of the International Agency for Research on Cancer of the World Health Organization estimated
Figure 2

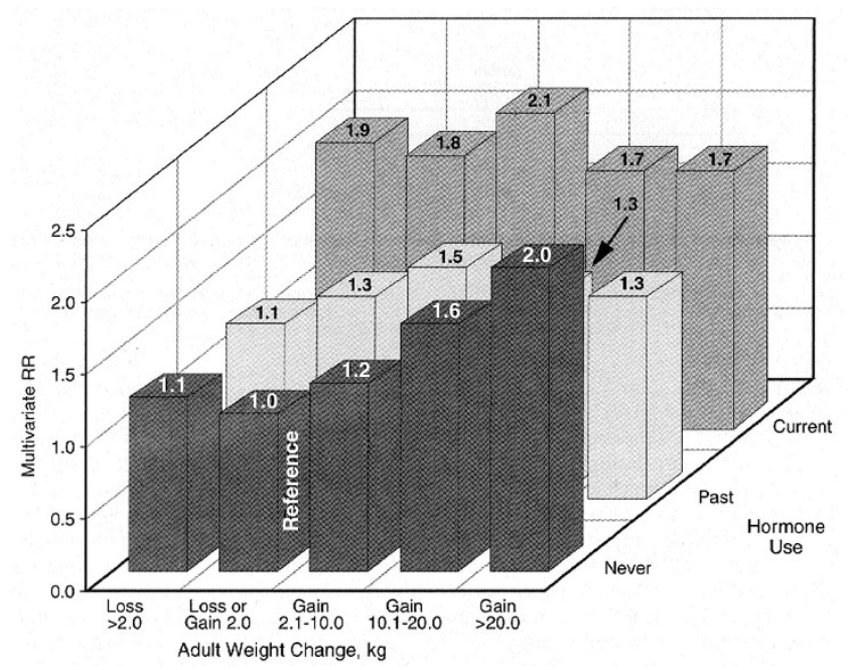

Weight gain, hormone use, and breast cancer. Relative risk (RR) of breast cancer by adult weight change and hormone use among postmenopausal women. RR was adjusted for age, height, history of benign diseases, family history of breast cancer, age at menarche, parity, age at first birth, age at menopause, and body mass index at age 18 years. From Huang and coworkers [31], with permission.

that there is a $20-40 \%$ decrease in breast cancer risk among the most physically active women, regardless of menopausal status, type, or intensity of activity [41]. A mechanism for this decrease in risk might be the lower levels of circulating ovarian hormones found in physically active women $[42,43]$.

In summary, energy balance appears to play an important role in human breast cancer. Rapid childhood growth rates accelerate the age at menarche and result in greater stature, both of which are associated with increased risk. Overweight is associated with a lower incidence of breast cancer before menopause. However, weight gain during adulthood is associated with a graded and substantial increase in postmenopausal breast cancer risk, which is seen most clearly in the absence of hormone replacement therapy.

\section{Dietary fiber and carbohydrate quality}

Diets that are high in fiber have been hypothesized to protect against breast cancer by inhibiting the intestinal reabsorption of biliary excreted estrogens. Recently, in a Swedish cohort including 342 cases [44], a lower risk for postmenopausal breast cancer $(\mathrm{RR}=0.58,95 \% \mathrm{Cl}=$ 0.40-0.84) for the highest compared with the lowest quintile of fiber intake was identified. However, other prospective studies have not been supportive of a link between fiber intake and breast cancer [45-49]. It is possible that particular fiber fractions are more important than total fiber intake. 
Terry and coworkers [48] reported on breast cancer risk associated with dietary fiber fractions. They found no associations between intake of total, soluble, insoluble, cereal, fruit, and vegetable fiber, as well as lignin and cellulose, and breast cancer risk among 89,835 women in the Canadian National Breast Screening Study. Similarly, no association was found with fiber fractions in the Nurses' Health Study [50].

Recent studies have raised the hypothesis that carbohydrate quality rather than absolute amount of intake may be important in breast cancer risk, particularly for premenopausal women. Most are retrospective studies, however, and more prospective studies are needed. One case-control study including 140 cases of premenopausal bilateral breast cancer reported an elevated risk for intake of sweetened beverages [51]: odds ratio $(95 \% \mathrm{Cl})=2.6$ $(1.2-5.8)$ for the highest versus the lowest quartile of intake. In a large (2569 cases), Italian, population-based, case-control study [52], both premenopausal and postmenopausal breast cancer patients had a higher mean dietary glycemic index - a measure of carbohydrate quality that is based on postprandial blood glucose. Comparing the highest with the lowest quintiles of glycemic index, the odds ratio $(95 \% \mathrm{Cl})$ was $1.36(1.14-1.64)$.

However, in a Swedish prospective study of dietary patterns including 1328 cases [53], no association was found between a 'Western' dietary pattern, including refined grains and sweets, and risk for breast cancer, even when stratified by age ( $40-49$ years versus $\geq 50$ years).

Because the adverse metabolic response to higher carbohydrate intake is exacerbated in the presence of insulin resistance [54,55], high carbohydrate or glycemic load intake might be expected to increase breast cancer risk primarily in overweight women. However, results were inconsistent in two studies that examined this association stratified by BMI $[49,50]$. In addition, intake of cereal fiber did not modify the association of glycemic load with breast cancer risk [50].

\section{Vitamin A}

Vitamin A consists of preformed vitamin A from animal sources, and carotenoids found primarily in fruits and vegetables. Many carotenoids are potent antioxidants and may provide a defense against reactive oxygen species that damage DNA. Vitamin A also regulates cell differentiation, and may thus prevent carcinogenesis.

In a cohort of Canadian women (519 cases) [46], a marginally significant protective association between total vitamin $A$ intake, preformed vitamin $A$ and $\beta$-carotene, and breast cancer was seen. With 14 years of follow-up in the Nurses' Health Study (2697 cases) [56], an inverse premenopausal women. This inverse association was primarily accounted for by intakes of $\beta$-carotene and lutein/zeaxanthin, and was strongest among women with a family history of breast cancer. However, in an extended follow-up of the Canadian cohort (1452 cases) and in a Swedish cohort (1271 cases), little overall association was seen between intake of carotenoids and breast cancer $[57,58]$.

An alternative to the dietary assessment of vitamin A intake is the measurement of vitamin A compounds in blood. In the two largest studies based on blood samples collected before diagnosis $[59,60]$, low levels of $\beta$ carotene and other carotenoids were associated with an approximately twofold increase in risk for breast cancer.

Thus, available data from observational studies suggest a possible protective effect of vitamin A intake, particularly carotenoids, on breast cancer risk, particularly in premenopausal women. Ideally, the effect of vitamin A supplements should be evaluated in randomized trials. However, the $\beta$-carotene arm of the Women's Health Study (a breast cancer prevention trial conducted in 40,000 women) was terminated in 1996 after reports that $\beta$-carotene supplements appeared to increase the risk for lung cancer among smoking men. Thus, data from randomized trials on specific carotenoids and breast cancer risk may never be available.

\section{Other antioxidants}

Vitamin $\mathrm{E}$ has inhibited mammary tumors in rodents in some experiments [61]. However, none of the published prospective studies has reported a significant inverse association $[46,56,58,62]$.

Vitamin C (ascorbic acid) can block the formation of carcinogenic nitrosoamines. In prospective studies no significant overall association between intake of vitamin $\mathrm{C}$ and breast cancer was observed $[46,56,62,63]$, including with long-term use of vitamin $\mathrm{C}$ supplements [56].

Selenium, an important component of the antioxidant enzyme glutathione peroxidase, inhibits cell proliferation and in animal studies protects against a variety of cancers, although usually at high levels of intake [64]. Individual selenium intake cannot be measured accurately by dietary assessment because the selenium content of foods depends on the geographic area in which the foods were grown. However, selenium levels in tissues such as blood and toenails do reflect intake [65]. In prospective studies $[66,67]$, no association between toenail selenium and risk for breast cancer was observed.

\section{Alcohol}

There is substantial evidence that alcohol consumption increases breast cancer risk. In a pooled analysis of the six 
Figure 3

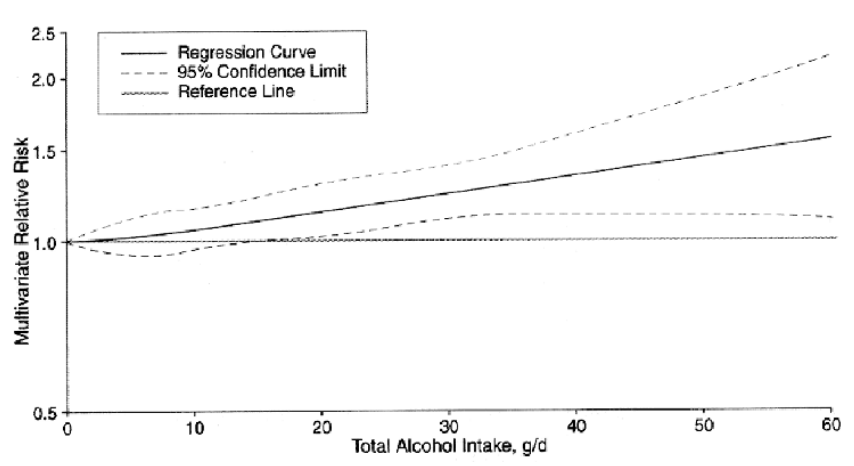

Alcohol intake and breast cancer. Nonparametric regression curve for the relationship between total alcohol intake and breast cancer. From Smith-Warner and coworkers [68], with permission.

largest cohort studies with data on alcohol and dietary factors [68], the risk for breast cancer increased monotonically with increasing intake of alcohol (Fig. 3). For a $10 \mathrm{~g} /$ day increase in alcohol, breast cancer risk increased by $9 \%(95 \% \mathrm{Cl}=4-13 \%)$. Adjustment for other breast cancer risk factors had little impact. Beer, wine, and liquor all contribute to the positive association, strongly suggesting that alcohol per se is responsible for the increased risk. In intervention studies, consumption of approximately one to two alcoholic drinks per day increased estrogen levels in premenopausal and postmenopausal women $[69,70]$, suggesting a mechanism by which alcohol may increase breast cancer risk.

In several large prospective studies, high intake of folic acid appeared to mitigate completely the excess risk for breast cancer due to alcohol [71-73]. This relationship was recently confirmed using plasma folic acid levels [74].

The public health recommendations for alcohol are complicated because consumption of one to two alcoholic beverages per day probably protects against cardiovascular disease. Because cardiovascular disease is the leading cause of death among women, moderate drinking is associated overall with a modest reduction in total mortality [75]. However, avoiding alcohol appears to be one of relatively few methods for reducing breast cancer risk, whereas many methods exist to reduce risk for cardiovascular disease. For women choosing to consume alcohol regularly, use of a multivitamin to ensure adequate folic acid intake may decrease breast cancer risk.

\section{Caffeine}

Speculation that caffeine may increase breast cancer risk followed a report that women with benign breast disease experienced symptom relief after eliminating caffeine from their diet. In prospective studies no increase in breast cancer risk has been seen $[76,77]$.

\section{Phytoestrogens}

Phytoestrogens in soy products have attracted attention because they are highly consumed in Asian countries that have low rates of cancer [78]. These isoflavone compounds, which include daidzen and genistein, can bind estrogen receptors but are much less potent than estradiol, and may act like tamoxifen by blocking the action of endogenous estrogens to reduce breast cancer risk.

Studies in Western populations with low soy intake have been unable to show an association with breast cancer risk [79]. In some case-control studies in Asian populations [80-82], soy intake, particularly during adolescence, was associated with lower breast cancer risk. However, in two others $[83,84]$, and in one prospective study from Japan [85], little relation was seen. However, a recent prospective study from Japan including 179 cases [86] reported a decreased risk for breast cancer when comparing the highest with the lowest quartile of isoflavone consumption $(\mathrm{RR}=0.46,95 \% \mathrm{Cl}=0.25-0.84)$. Similar results were found for intake of miso soup, but not soy foods, and results were strongest for postmenopausal women. More prospective studies are needed.

Conceivably, high-dose phytoestrogens could even increase overall estrogenic activity among postmenopausal women. In a cross-sectional study [87] it was found that women consuming more soy had more mammographically dense breasts, which is a known risk factor for breast cancer. In addition, randomized controlled feeding trials have found that women consuming soy had increased markers of cell proliferation in their breasts $[88,89]$.

\section{Specific foods}

Foods contain an extremely complex mix of essential nutrients and other compounds that could influence breast cancer risk in ways not detected by study of individual nutrients.

Inverse associations between intakes of fruits and vegetables and breast cancer risk have been reported in a notably large number of case-control studies [90]. However, in the pooled analysis of eight large prospective studies (7377 cases among 351,825 women), only weak and nonsignificant associations were seen with increasing consumption of fruit and vegetables [91]. Comparing highest with lowest quartiles, RRs were $0.93(95 \% \mathrm{Cl}=$ 0.86-1.00) for total fruits, $0.96(0.89-1.04)$ for total vegetables, and $0.93(0.86-1.00)$ for total fruits plus vegetables. A thorough search among specific fruits and vegetables and botanical groups did not reveal any significant associations.

Associations between red meat consumption and risk for breast cancer have been reported sporadically [92]. 
However, as previously mentioned, breast cancer rates among UK nuns who ate little to no meat were similar to rates among single women from the general population [6]. In the pooled analysis of large cohort studies (7379 cases) [93], no association was seen with consumption of red meat, white meat, or dairy products. In an analysis that retrospectively assessed degree of cooking [94], consumption of well-done red meat was associated with breast cancer incidence. This will require evaluation in prospective analyses.

\section{Conclusion}

The role of specific dietary factors in breast cancer causation is not completely resolved. Enthusiasm for the hypothesis that dietary fat intake was responsible for the high rates of breast cancer rates in Western countries was based largely on the weakest form of epidemiologic evidence - ecological correlation studies. Results from prospective studies do not support the concept that fat intake in middle life has a major relation to breast cancer risk during up to 14 years of follow up. High-energy intake in relation to physical activity, which accelerates growth and the onset of menstruation during childhood, leads to weight gain in middle life and thus can contribute substantially to breast cancer risk. These effects of energy balance clearly account for an important part of international differences in breast cancer rates. Some evidence suggests that vitamin A or other compounds in vitamin A-rich foods may reduce breast cancer risk modestly, but these findings are not conclusive and deserve further consideration. Alcohol intake is the bestestablished specific dietary risk factor for breast cancer, and studies demonstrating that even moderate alcohol intake increases endogenous estrogen levels provide a potential mechanism, thus supporting a causal interpretation. Hypotheses relating childhood and adolescent diet to breast cancer risk decades later will be more difficult to test. Nevertheless, the available evidence that breast cancer risk can be reduced by avoiding weight gain during adult years and by limiting alcohol consumption is strong.

\section{Competing interests}

None declared

\section{Acknowledgement}

This article is adapted in part from an earlier review presented in Epidemiology and Nongenetic Causes of Breast Cancer [95].

\section{References}

1. Buell P: Changing incidence of breast cancer in JapaneseAmerican women. J Natl Cancer Inst 1973, 51:1479-1483.

2. Ip C: Quantitative assessment of fat and calorie as risk factors in mammary carcinogenesis in an experimental model. In Recent Progress in Research on Nutrition and Cancer. Edited by Mettlin CJ, Aoki K. Proceedings of a Workshop Sponsored by the International Union Against Cancer; Nagoya, Japan; 1-3 November 1989. New York, NY: Wiley-Liss Inc., 1990:107117.

3. Beth M, Berger MR, Aksoy M, Schmahl D: Comparison between the effects of dietary fat level and of calorie intake on methyl- nitrosourea-induced mammary carcinogenesis in female SD rats. Int J Cancer 1987, 39:737-744.

4. Armstrong B, Doll R: Environmental factors and cancer incidence and mortality in different countries, with special reference to dietary practices. Int J Cancer 1975, 15:617-631.

5. Phillips RL, Garfinkel L, Kuzma JW, Beeson WL, Lotz T, Brin B: Mortality among California Seventh-Day Adventists for selected cancer sites. J Natl Cancer Inst 1980, 65:1097-1107.

6. Kinlen $\sqcup$ : Meat and fat consumption and cancer mortality: a study of strict religious orders in Britain. Lancet 1982, 1:946-949.

7. Howe GR, Hirohata T, Hislop TG, Iscovich JM, Yuan JM, Katsouyanni K, Lubin F, Marubini E, Modan B, Rohan T, Toniolo P, Shunzhang $Y$ : Dietary factors and risk of breast cancer: combined analysis of 12 case-control studies. J Natl Cancer Inst 1990, 82:561-569.

8. Giovannucci E, Stampfer MJ, Colditz GA, Manson JE, Rosner BA, Longnecker M, Speizer FE, Willett WC: A comparison of prospective and retrospective assessments of diet in the study of breast cancer. Am J Epidemiol 1993, 137:502-511.

9. Potischman N, Weiss HA, Swanson CA, Coates RJ, Gammon MD, Malone KE, Brogan D, Stanford JL, Hoover RN, Brinton LA: Diet during adolescence and risk of breast cancer among young women. J Natl Cancer Inst 1998, 90:226-233.

10. Frazier AL, Li L, Cho E, Willett WC, Colditz GA: Adolescent diet and risk of breast cancer. Cancer Causes Control 2004, 15:7382.

11. Hunter DJ, Spiegelman D, Adami HO, Beeson L, van den Brandt PA, Folsom AR, Fraser GE, Goldbohm RA, Graham S, Howe GR, Kushi LH, Marshall JR, McDermott A, Miller AB, Speizer FE, Wolk A, Yaun S-S, Willett W: Cohort studies of fat intake and the risk of breast cancer: a pooled analysis. N Engl J Med 1996, 334:356-361.

12. Holmes MD, Hunter DJ, Colditz GA, Stampfer MJ, Hankinson SE Speizer FE, Rosner B, Willett WC: Association of dietary intake of fat and fatty acids with risk of breast cancer. JAMA 1999, 281:914-920.

13. Prentice R: Measurement error and results from analytic epidemiology: dietary fat and breast cancer. J Natl Cancer Inst 1996, 88:1738-1747.

14. Hunter DJ, Spiegelman D, Willett WC, for the Pooling of Prospective Studies Investigators: Dietary fat and breast cancer [letter]. J Natl Cancer Inst 1998, 90:1303-1305.

15. Anonymous: Design of the Women's Health Initiative clinical trial and observational study. The Women's Health Initiative Study Group. Controlled Clin Trials 1998, 19:61-109.

16. Chlebowski RT, Grosvenor M: The scope of nutrition intervention trials with cancer-related endpoints. Cancer 1994, Suppl: 2734-2738.

17. Rock CL, Demark-Wahnefried W: Can lifestyle modification increase survival in women diagnosed with breast cancer? J Nutr 2002, Suppl:3504S-3507S.

18. Freedman LS, Prentice RL, Clifford C: Dietary fat and breast cancer: where we are. J Natl Cancer Inst 1993, 85:764-765.

19. Smith-Warner SA, Spiegelman D, Adami HO, Beeson WL, van den Brandt PA, Folsom AR, Fraser GE, Freudenheim JL, Goldbohm RA, Graham S, Kushi LH, Miller AB, Rohan TE, Speizer FE, Toniolo P, Willett WC, Wolk A, Zeleniuch-Jacquotte A, Hunter DJ: Types of dietary fat and breast cancer: a pooled analysis of cohort studies. Int J Cancer 2001, 92:767-774.

20. Cho E, Spiegelman D, Hunter DJ, Chen WY, Stampfer MJ, Colditz GA, Willett WC: Premenopausal fat intake and risk of breast cancer. J Natl Cancer Inst 2003, 95:1079-1085.

21. Tretli S, Gaard M: Lifestyle changes during adolescence and risk of breast cancer: an ecologic study of the effect of World War II in Norway. Cancer Causes Control 1996, 7:507-512.

22. Elias SG, Peeters PH, Grobbee DE, van Noord PA: Breast cancer risk after caloric restriction during the 1944-1945 Dutch famine. J Natl Cancer Inst 2004, 96:539-546.

23. Hunter DJ, Willett WC: Diet, body size, and breast cancer. Epidemiol Rev 1993, 15:110-132.

24. Swanson CA, Jones DY, Schatzkin A, Brinton LA, Ziegler RG: Breast cancer risk assessed by anthropometry in the NHANES I epidemiological follow-up study. Cancer Res 1988, 48:5363-5367.

25. Vatten LJ, Kvinnsland S: Body height and risk of breast cancer. A prospective study of 23,831 Norwegian women. $\mathrm{Br} J \mathrm{Cancer}$ 1990, 61:881-885. 
26. Vatten LJ, Kvinnsland S: Prospective study of height, body mass index and risk of breast cancer. Acta Oncol 1992, 31: 195-200.

27. van den Brandt PA, Spiegelman D, Yaun SS, Adami HO, Beeson L, Folsom AR, Fraser G, Goldbohm RA, Graham S, Kushi L, Marshall JR, Miller AB, Rohan T, Smith-Warner SA, Speizer FE, Willett WC, Wolk A, Hunter DJ: Pooled analysis of prospective cohort studies on height, weight, and breast cancer risk. Am J Epidemiol 2000, 152:514-527.

28. Meyer F, Moisan J, Marcoux D, Bouchard C: Dietary and physical determinants of menarche. Epidemiology 1990, 1:377-381.

29. Merzenich $\mathrm{H}$, Boeing $\mathrm{H}$, Wahrendorf J: Dietary fat and sports activity as determinants for age at menarche. Am J Epidemiol 1993, 138:217-224.

30. Chen J, Campbell TC, Junyao L: Diet, Life-style, and Mortality in China: a Study of the Characteristics of 65 Chinese Counties. Oxford, England: Oxford University Press; 1990.

31. Huang Z, Hankinson SE, Colditz GA, Stampfer MJ, Hunter DJ, Manson JE, Hennekens $\mathrm{CH}$, Rosner B, Speizer FE, Willett WC: Dual effects of weight and weight gain on breast cancer risk. JAMA 1997, 278:1407-1411.

32. Rich-Edwards JW, Goldman MB, Willett WC, Hunter DJ, Stampfer MJ, Colditz GA, Manson JE: Adolescent body mass index and infertility caused by ovulatory disorder. Am J Obstet Gynecol 1994, 171:171-177.

33. Garland M, Hunter DJ, Colditz GA, Manson JE, Stampfer MJ, Spiegelman D, Speizer F, Willett WC: Menstrual cycle characteristics and history of ovulatory infertility in relation to breast cancer risk in a large cohort of US women. Am J Epidemiol 1998, 147:636-643.

34. Hankinson SE, Willett WC, Manson JE, Hunter DJ, Colditz GA, Stampfer MJ, Longcope C, Speizer FE. Alcohol, height, and adiposity in relation to estrogen and prolactin levels in postmenopausal women. J Natl Cancer Inst 1995, 87:1297-1302.

35. Barnes-Josiah D, Potter JD, Sellers TA, Himes JH: Early body size and subsequent weight gain as predictors of breast cancer incidence (lowa, United States). Cancer Causes Control 1995, 6:112-118.

36. Wenten M, Gilliland FD, Baumgartner K, Samet JM: Associations of weight, weight change, and body mass with breast cancer risk in Hispanic and non-Hispanic white women. Ann Epidemiol 2002, 12:435-444.

37. Trentham-Dietz A, Newcomb PA, Egan KM, Titus-Ernstoff L, Baron JA, Storer BE, Stampfer M, Willett WC: Weight change and risk of postmenopausal breast cancer (United States). Cancer Causes Control 2000, 11:533-542.

38. Le Marchand L, Kolonel LN, Earle ME, Mi MP: Body size at different periods of life and breast cancer risk. Am J Epidemiol 1988, 128:137-152.

39. Morimoto LM, White E, Chen Z, Chlebowski RT, Hays J, Kuller L, Lopez AM, Manson J, Margolis KL, Muti PC, Stefanick ML, McTiernan A: Obesity, body size, and risk of postmenopausal breast cancer: the Women's Health Initiative (United States). Cancer Causes Control 2002, 13:741-751.

40. Key TJ, Appleby PN, Reeves GK, Roddam A, Dorgan JF, Longcope C, Stanczyk FZ, Stephenson HE Jr, Falk RT, Miller R, Schatzkin A, Allen DS, Fentiman IS, Key TJ, Wang DY, Dowsett M, Thomas HV, Hankinson SE, Toniolo P, Akhmedkhanov A, Koenig K, Shore RE, Zeleniuch-Jacquotte A, Berrino F, Muti $P$, Micheli A, Krogh V, Sieri S, Pala V, Venturelli E, Secreto G, Barrett-Connor E, Laughlin GA, Kabuto M, Akiba S, Stevens RG, Neriishi K, Land CE, Cauley JA, Kuller LH, Cummings SR, Helzlsouer KJ, Alberg AJ, Bush TL, Comstock GW, Gordon GB, Miller SR, Longcope C, Endogenous Hormones Breast Cancer Collaborative Group: Body mass index, serum sex hormones, and breast cancer risk in postmenopausal women. J Natl Cancer Inst 2003, 95:1218-1226.

41. Bianchini $F$, Kaaks $R$, Vainio $H$ : Weight control and physical activity in cancer prevention. Obes Rev 2002, 3:5-8.

42. Broocks A, Pirke KM, Schweiger U, Tuschl RJ, Laessle RG, Strowitzki T, Horl E, Horl T, Haas W, Jeschke D: Cyclic ovarian function in recreational athletes. J App/ Physiol 1990, 68:20832086

43. Bullen BA, Skrinar GS, Beitins IZ, von Mering G, Turnbull BA, McArthur JW: Induction of menstrual disorders by strenuous exercise in untrained women. $N$ Engl J Med 1985, 312:13491353.
44. Mattisson I, Wirfalt E, Johansson U, Gullberg B, Olsson H, Berglund G: Intakes of plant foods, fibre and fat and risk of breast cancer: a prospective study in the Malmo Diet and Cancer cohort. Br J Cancer 2004, 90:122-127.

45. Willett WC, Hunter DJ, Stampfer MJ, Colditz G, Manson JE, Spiegelman D, Rosner B, Hennekens CH, Speizer FE: Dietary fat and fiber in relation to risk of breast cancer. JAMA 1992, 268: 2037-2044.

46. Rohan TE, Howe GR, Friedenreich CM, Jain M, Miller AB: Dietary fiber, vitamins $A, C$, and $E$, and risk of breast cancer: a cohort study. Cancer Causes Control 1993, 4:29-37.

47. Graham S, Zielezny M, Marshall J, Priore R, Freudenheim J, Brasure J, Haughey B, Nasca P, Zdeb M: Diet in the epidemiology of postmenopausal breast cancer in the New York State Cohort. Am J Epidemiol 1992, 136:1327-1337.

48. Terry $P$, Jain M, Miller AB, Howe GR, Rohan TE: No association among total dietary fiber, fiber fractions, and risk of breast cancer. Cancer Epidemiol Biomarkers Prev 2002, 11:15071508.

49. Cho E, Spiegelman D, Hunter D, Chen WY, Willett WC: Premenopausal Dietary Carbohydrate, Glycemic Index, Glycemic Load, and Fiber in Relation to Risk of Breast Cancer, Toronto: American Association for Cancer Research; 2003.

50. Holmes MD, Liu S, Hankinson SE, Colditz GA, Hunter DJ, Willett WC: Dietary carbohydrates, fiber, and breast cancer risk. Am J Epidemiol 2004, 159:732-739.

51. Witte JS, Ursin G, Siemiatycki J, Thompson WD, Paganini-Hill A, Haile RW: Diet and premenopausal bilateral breast cancer: a case-control study. Breast Cancer Res Treat 1997, 42:243-251.

52. Augustin LS, Dal Maso L, La Vecchia C, Parpinel M, Negri E, Vaccarella S, Kendall CW, Jenkins DJ, Francesch S: Dietary glycemic index and glycemic load, and breast cancer risk: a case-control study. Ann Oncol 2001, 12:1533-1538.

53. Terry P, Suzuki R, Hu FB, Wolk A: A prospective study of major dietary patterns and the risk of breast cancer. Cancer Epidemiol Biomarkers Prev 2001, 10:1281-1285.

54. Liu S, Manson JE, Stampfer MJ, Holmes MD, Hu FB, Hankinson SE, Willett WC: Dietary glycemic load assessed by food-frequency questionnaire in relation to plasma high-densitylipoprotein cholesterol and fasting plasma triacylglycerols in postmenopausal women. Am J Clin Nutr 2001, 73:560-566.

55. Liu S, Manson JE, Buring JE, Stampfer MJ, Willett WC, Ridker PM: Relation between a diet with a high glycemic load and plasma concentrations of high-sensitivity $\mathrm{C}$-reactive protein in middle-aged women. Am J Clin Nutr 2002, 75:492-498.

56. Zhang S, Hunter DJ, Forman MR, Rosner BA, Speizer FE, Colditz GA, Manson JE, Hankinson SE, Willett WC: Dietary carotenoids, and vitamins $\mathrm{A}, \mathrm{C}$. and $\mathrm{E}$ and risk of breast cancer. $J \mathrm{Nat}$ Cancer Inst 1999, 91:547-556.

57. Terry $P$, Jain $M$, Miller AB, Howe GR, Rohan TE: Dietary carotenoids and risk of breast cancer. Am J Clin Nutr 2002, 76:883-888.

58. Michels KB, Holmberg L, Bergkvist L, Ljung $H$, Bruce A, Wolk A: Dietary antioxidant vitamins, retinol, and breast cancer incidence in a cohort of Swedish women. Int J Cancer 2001, 91: 563-567.

59. Toniolo P, Van Kappel AL, Akhmedkhanov A, Ferrari P, Kato I, Shore RE, Riboli E: Serum carotenoids and breast cancer. Am $J$ Epidemiol 2001, 153:1142-1147.

60. Sato R, Helzlsouer KJ, Alberg AJ, Hoffman SC, Norkus EP, Comstock GW: Prospective study of carotenoids, tocopherols, and retinoid concentrations and the risk of breast cancer. Cancer Epidemiol Biomarkers Prev 2002, 11:451-457.

61. King MM, McCay PB: Modulation of tumor incidence and possible mechanisms of inhibition of mammary carcinogenesis by dietary antioxidants. Cancer Res 1983, Suppl:2485s-2490s.

62. Verhoeven DT, Assen N, Goldbohm RA, Dorant E, van 't Veer P, Sturmans F, Hermus RJ, van den Brandt PA: Vitamins C and E, retinol, beta-carotene and dietary fibre in relation to breast cancer risk: a prospective cohort study. $\mathrm{Br} J$ Cancer 1997, 75: 149-155.

63. Kushi LH, Fee RM, Sellers TA, Zheng W, Folsom AR: Intake of vitamins $A, C$, and $E$ and postmenopausal breast cancer. The lowa Women's Health Study. Am J Epidemiol 1996, 144:165174.

64. Ip C: The chemopreventive role of selenium in carcinogenesis. Adv Exp Med Biol 1986, 206:431-447. 
65. Hunter DJ: Biochemical indicators of dietary intake. In Nutritional Epidemiology. Edited by Willett WC. New York: Oxford University Press; 1990:143-216.

66. Hunter DJ, Morris JS, Stampfer MJ, Colditz GA, Speizer FE, Willett WC: A prospective study of selenium status and breast cancer risk. JAMA 1990, 264:1128-1131.

67. van den Brandt PA, Goldbohm RA, van't Veer P, Bode P, Dorant $\mathrm{E}$, Hermus RJ, Sturmans F: Toenail selenium levels and the risk of breast cancer. Am J Epidemiol 1994, 140:20-26.

68. Smith-Warner SA, Spiegelman D, Yaun SS, van den Brandt PA, Folsom AR, Goldbohm RA, Graham S, Holmberg L, Howe GR, Marshall JR, Miller AB, Potter JD, Speizer FE, Willett WC, Wolk A, Hunter DJ: Alcohol and breast cancer in women: a pooled analysis of cohort studies. JAMA 1998, 279:535-540.

69. Reichman ME, Judd JT, Longcope C, Schatzkin A, Clevidence BA, Nair PP, Campbell WS, Taylor PR: Effects of alcohol consumption on plasma and urinary hormone concentrations in premenopausal women. J Natl Cancer Inst 1993, 85:722-727.

70. Ginsburg ES, Walsh BW, Gao X, Gleason RE, Feltmate C, Barbieri RL: The effect of acute ethanol ingestion on estrogen levels in postmenopausal women using transdermal estradiol. J Soc Gynecol Investig 1995, 2:26-29.

71. Zhang S, Hunter DJ, Hankinson SE, Giovannucci EL, Rosner BA, Colditz GA, Speizer FE, Willett WC: A prospective study of folate intake and the risk of breast cancer. JAMA 1999, 281: 1632-1637

72. Sellers TA, Kushi LH, Cerhan JR, Vierkant RA, Gapstur SM, Vachon CM, Olson JE, Therneau TM, Folsom AR: Dietary folate intake, alcohol, and risk of breast cancer in a prospective study of postmenopausal women. Epidemiology 2001, 12:420428.

73. Rohan TE, Jain MG, Howe GR, Miller AB: Dietary folate consumption and breast cancer risk. J Natl Cancer Inst 2000, 92: 266-269.

74. Zhang SM, Willett WC, Selhub J, Hunter DJ, Giovannucci EL, Holmes MD, Colditz GA, Hankinson SE: Plasma folate, vitamin B6, vitamin B12, homocysteine, and risk of breast cancer. $J$ Natl Cancer Inst 2003, 95:373-380.

75. Fuchs CS, Stampfer MJ, Colditz GA, Giovannucci EL, Manson JE, Kawachi I, Hunter DJ, Hankinson SE, Hennekens CH, Rosner B: Alcohol consumption and mortality among women. $N$ Engl $J$ Med 1995, 332:1245-1250.

76. Folsom AR, McKenzie DR, Bisgard KM, Kushi LH, Sellers TA: No association between caffeine intake and postmenopausal breast cancer incidence in the lowa Women's Health Study. Am J Epidemiol 1993, 138:380-383.

77. Vatten LJ, Solvoll K, Loken EB: Coffee consumption and the risk of breast cancer. A prospective study of 14,593 Norwegian women. Br J Cancer 1990, 62:267-270.

78. Steinmetz KA, Potter JD: Vegetables, fruit, and cancer. II. Mechanisms. Cancer Causes Control 1991, 2:427-442.

79. Keinan-Boker L, van Der Schouw YT, Grobbee DE, Peeters PH: Dietary phytoestrogens and breast cancer risk. Am J Clin Nutr 2004, 79:282-288.

80. Lee HP, Gourley L, Duffy SW, Esteve J, Lee J, Day NE: Dietary effects on breast-cancer risk in Singapore. Lancet 1991, 337: 1197-1200.

81. Shu XO, Jin F, Dai Q, Wen W, Potter JD, Kushi LH, Ruan Z, Gao YT, Zheng W: Soyfood intake during adolescence and subsequent risk of breast cancer among Chinese women. Cancer Epidemiol Biomarkers Prev 2001, 10:483-488.

82. Wu AH, Wan P, Hankin J, Tseng CC, Yu MC, Pike MC: Adolescent and adult soy intake and risk of breast cancer in AsianAmericans. Carcinogenesis 2002, 23:1491-1496.

83. Yuan JM, Wang QS, Ross RK, Henderson BE, Yu MC: Diet and breast cancer in Shanghai and Tianjin, China. $\mathrm{Br} J$ Cancer 1995, 71:1353-1358.

84. Yuan JM, Yu MC, Ross RK, Gao YT, Henderson BE: Risk factors for breast cancer in Chinese women in Shanghai. Cancer Res 1988, 48:1949-1953.

85. Key TJ, Sharp GB, Appleby PN, Beral V, Goodman MT, Soda M, Mabuchi K: Soya foods and breast cancer risk: a prospective study in Hiroshima and Nagasaki, Japan. Br J Cancer 1999, 81:1248-1256.

86. Yamamoto S, Sobue T, Kobayashi M, Sasaki S, Tsugane S: Soy, isoflavones, and breast cancer risk in Japan. J Natl Cancer Inst 2003, 95:906-913.
87. Maskarinec G, Meng L: An investigation of soy intake and mammographic characteristics in Hawaii. Breast Cancer Res 2001, 3:134-141.

88. Hargreaves DF, Potten CS, Harding C, Shaw LE, Morton MS, Roberts SA, Howell A, Bundred NJ: Two-week dietary soy supplementation has an estrogenic effect on normal premenopausal breast. J Clin Endocrinol Metab 1999, 84: 4017-4024.

89. McMichael-Phillips DF, Harding C, Morton M, Roberts SA, Howell A, Potten CS, Bundred NJ: Effects of soy-protein supplementation on epithelial proliferation in the histologically normal human breast. Am J Clin Nutr 1998, Suppl:1431S-1435S

90. Fund WCRL Food, Nutrition and the Prevention of Cancer: a Global Perspective. Washington, DC: American Institutue for Cancer Research; 1997.

91. Smith-Warner SA, Spiegelman D, Yaun SS, Adami HO, Beeson WL, van den Brandt PA, Folsom AR, Fraser GE, Freudenheim JL, Goldbohm RA, Graham S, Miller AB, Potter JD, Rohan TE, Speizer FE, Toniolo P, Willett WC, Wolk A, Zeleniuch-Jacquotte $A$, Hunter DJ: Intake of fruits and vegetables and risk of breast cancer: a pooled analysis of cohort studies. JAMA 2001, 285: 769-776.

92. Toniolo P, Riboli E, Shore RE, Pasternack BS: Consumption of meat, animal products, protein, and fat and risk of breast cancer: a prospective cohort study in New York. Epidemiology 1994, 5:391-397.

93. Missmer SA, Smith-Warner SA, Spiegelman D, Yaun SS, Adami $\mathrm{HO}$, Beeson WL, van den Brandt PA, Fraser GE, Freudenheim JL, Goldbohm RA, Graham S, Kushi LH, Miller AB, Potter JD, Rohan TE, Speizer FE, Toniolo P, Willett WC, Wolk A, ZeleniuchJacquotte $A$, Hunter DJ: Meat and dairy food consumption and breast cancer: a pooled analysis of cohort studies. Int $J$ Epidemiol 2002, 31:78-85.

94. Zheng W, Gustafson DR, Sinha R, Cerhan JR, Moore D, Hong CP, Anderson KE, Kushi LH, Sellers TA, Folsom AR: Well-done meat intake and the risk of breast cancer. J Natl Cancer Inst 1998, 90:1724-1729.

95. Willett WC, Rockhill B, Hankinson SE, Hunter DJ, Colditz G: Epidemiology and nongenetic causes of breast cancer. In Diseases of the Breast. Edited by Harris JR, Lippman ME, Osborne CK. Philadelphia: Lippincott Williams \& Wilkins; 2004:223-276.

96. Willett WC, Hunter DJ, Stampfer MJ, Colditz G, Manson JE, Spiegelman D, Rosner B, Hennekens CH, Speizer FE: Dietary fat and fiber in relation to risk of breast cancer. An 8-year followup. JAMA 1992, 268:2037-2044.

97. Howe GR, Friedenreich CM, Jain M, Miller AB: A cohort study of fat intake and risk of breast cancer. J Natl Cancer Inst 1991, 83:336-340.

98. Graham S, Hellmann R, Marshall J, Freudenheim J, Vena J, Swanson M, Zielezny M, Nemoto T, Stubbe N, Raimondo T: Nutritional epidemiology of postmenopausal breast cancer in western New York. Am J Epidemiol 1991, 134:552-566.

99. Kushi LH, Sellers TA, Potter JD, Nelson CL, Munger RG, Kaye SA Folsom AR: Dietary fat and postmenopausal breast cancer. $J$ Natl Cancer Inst 1992, 84:1092-1099.

100. van den Brandt PA, van't Veer P, Goldbohm RA, Dorant E Volovics A, Hermus RJ, Sturmans F: A prospective cohort study on dietary fat and the risk of postmenopausal breast cancer. Cancer Res 1993, 53:75-82.

101. Wolk A, Bergstrom R, Hunter D, Willett W, Ljung $H$, Holmberg L, Bergkvist L, Bruce A, Adami HO: A prospective study of association of monounsaturated fat and other types of fat with risk of breast cancer. Arch Intern Med 1998, 158:41-45.

102. Velie E, Kulldorff M, Schairer C, Block G, Albanes D, Schatzkin A: Dietary fat, fat subtypes, and breast cancer in postmenopausal women: a prospective cohort study. J Natl Cancer Inst 2000, 92:833-839.

103. Horn-Ross PL, Hoggatt KJ, West DW, Krone MR, Stewart SL, Anton H, Bernstei CL, Deapen D, Peel D, Pinder R, Reynolds P Ross RK, Wright W, Ziogas A: Recent diet and breast cancer risk: the California Teachers Study (USA). Cancer Causes Control 2002, 13:407-415.

104. Mills PK, Beeson WL, Phillips RL, Fraser GE: Dietary habits and breast cancer incidence among Seventh-day Adventists. Cancer 1989, 64:582-590. 